\section{Category}

Metal-Catalyzed Asymmetric Synthesis and Stereoselective Reactions

\section{Key words}

\section{hydrogenation}

$\alpha$-hydroxy- $\beta$-amino acids

rhodium
Q. WANG, W. HUANG, H. YUAN, Q. CAI, L. CHEN, H. LV,* X. ZHANG* (WUHAN UNIVERSITY, P. R. OF CHINA)

Rhodium-Catalyzed Enantioselective Hydrogenation of Tetrasubstituted $\alpha$-Acetoxy $\beta$-Enamido Esters: A New Approach to Chiral $\alpha$-Hydroxy- $\beta$-amino Acid Derivatives

J. Am. Chem. Soc. 2014, 136, 16120-16123.

\title{
Rhodium-Catalyzed Enantioselective Hydrogenation of Enamido Esters
}
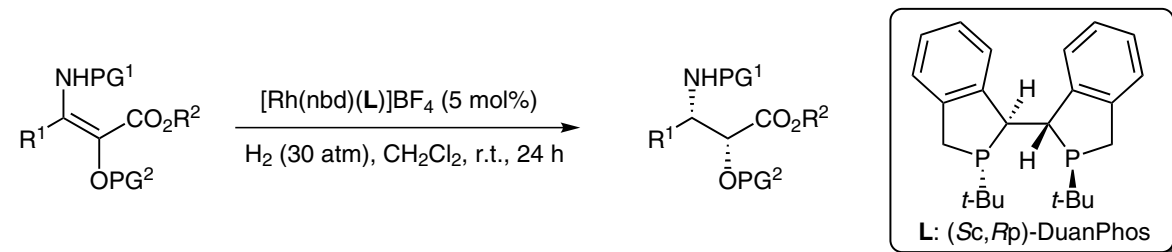<smiles>CCOC(=O)C(c1ccccc1)C(N)OC</smiles><smiles>COC(C(C)=O)C(N)c1ccccc1</smiles>

$98 \%$ yield $97 \%$ ee<smiles>COC(=O)[C@H](NC(C)=O)c1ccc(Br)cc1</smiles>

$97 \%$ yield $97 \%$ ee
$94 \%$ yield $96 \%$ ee<smiles>CO[C@H](N)[C@H](NC(C)=O)OC(C)=O</smiles>

$96 \%$ yield $95 \%$ ee<smiles>COc1ccc(C(N)C(O[Na])C(C)=O)cc1</smiles>

$94 \%$ yield $96 \%$ ee<smiles>CC(=O)O[C@@H](C(C)=O)[C@@H](C)N</smiles><smiles>CC(=O)C(C)C(Cc1ccc(F)cc1)C(C)=O</smiles>

$97 \%$ yield $96 \%$ ee

Synthesis of the taxol C13 side chain:
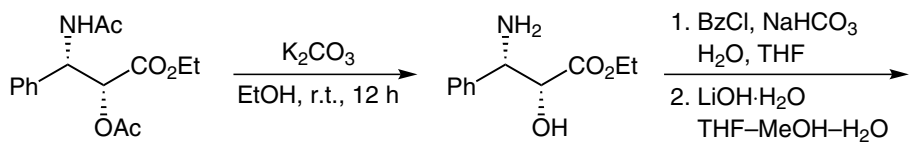<smiles>[NH3+]C(c1ccccc1)C(O)C(=O)O</smiles>

$89 \%$ yield<smiles>COC(=O)C(OC(C)=O)C(C)C</smiles>

ŌBz

$95 \%$ yield $86 \%$ ee

Significance: $L v$, Zhang and colleagues present a rhodium-catalyzed asymmetric hydrogenation of $\alpha$-acetoxy $\beta$-enamido esters. A series of chiral $\alpha$-hydroxy- $\beta$-amino acid derivatives were prepared in high yields (up to 98\%) with excellent enantioselectivities (up to $97 \%$ ee).
Comment: $\left[\mathrm{Rh}(\mathrm{nbd})(\mathrm{Sc}, \mathrm{Rp})-\right.$ DuanPhos] $\mathrm{BF}_{4}$ is found to be an effective catalyst for the enantioselective hydrogenation of tetrasubstituted enamides. The synthetic utility of this method is demonstrated by the synthesis of biologically important molecules. 